\title{
Currency Substitution and Central Bank Independence in the Central and Eastern European Economies
}

\author{
Sylvain Bouyon \\ Université Lille I \\ Laboratoire EQUIPPE
}

\begin{abstract}
This paper examines the extent to which the confrontation between the authorities implementing the monetary policy and the private agents asking for foreign currencies can influence the global process of currency substitution. The choice of an appropriate monetary policy depends on an original timeinconsistency problem where a partly-independent and conservative central bank is faced with a type of monetary targeting. The motives of the private agents in asking for foreign currencies are precautionary and/or speculative. We obtain the optimal growth of the aggregate in foreign currencies, which negatively depends on transparency, central bank credibility and inflation instability of the economy linked with the currency, and positively on inflation instability of the domestic economy. Then, we propose different measures of these determinants and we econometrically test this optimum in the economies of Central and Eastern Europe. The results are consistent with empirical literature on the macroeconomic determinants of dollarization. However, in this paper, the complexity of currency substitution is better illustrated and an empirical approach in relation to the institutional determinants of currency substitution is provided.
\end{abstract}

- JEL Classification: C23, E5, F41

- Key Words: currency substitution, transition economies, legal central bank independence, actual central bank independence

\footnotetext{
*Sylvain Bouyon: Universite Lille I, Laboratoire EQUIPPE, Rue Louis Hap 198, 1040 Bruxelles, Belgium, Tel: 00324941413 62, e-mail: sylvain.bouyon@bnymellon.com.

(2009-Center for International Economics, Sejong Institution, Sejong University, All Rights Reserved.
} 


\section{Introduction}

An important part of the empirical literature dealing with the dollarization of domestic savings focuses on the macroeconomic determinants of this original monetary phenomenon and generally concludes that inappropriate monetary policy, unstable inflation and depreciations will lead to increasing dollarization. Thomas (1985) and his portfolio in a dollarized economy inspired some of these papers (Ize and Levy Yeyati, (2003)), which empirically test the relationship between these determinants and dollarization. One of the main limits of this literature is to disregard the institutional impact.

Another important strand of this literature has concentrated on the role of the institutions in influencing the process of dollarization. Theoretical analyses (Cowan and Do (2003)) show that credibility of the central bank is essential to avoid suboptimal dollarization. According to that paper, under imperfect information, prejudgments about the Central Bank induce excess dollarization liabilities, which in turn limit the ability of the Central Bank to conduct an optimal monetary policy. However, this ability of the dollarization to influence monetary policy has not been tested. Moreover, as banking and monetary systems were inexistent at the beginning of the transition, balance sheet effects due to the dollarization of the domestic liabilities were very limited in the Central and Eastern European (CEE) economies until the beginning of the 2000s. The currency substitution in the CEE economies mainly affected monetary aggregates until the beginning of the 2000s. From now on, we will deal only with the dollarization and euroization of deposits.

In terms of figures, most of the Central Eastern European economies have undergone medium or high rates of currency substitution since the beginning of their transition from a communist system to a capitalist system. As we can observe in the Table in Annex 1, in 1996 the rate is about 27\% for the Central Eastern European economies; $34 \%$ for the CIS economies, $35 \%$ for Latin America ${ }^{1}$, and $8 \%$ for our group of industrial economies. ${ }^{2}$ For 2005 , the rate is $27 \%$ for CEE, 48.4\% for CIS, $47.4 \%$ for Latin America and 8.8\% for Industrial Economies. On

\footnotetext{
${ }^{1}$ However, we can observe big differences between some economies inside each group. In the CEE group, the rate of dollarization for Croatia is about $67 \%$ in 1996 while it is just $11 \%$ for Slovakia. For the CIS economies, Armenia underwent a rate of financial dollarization of $59 \%$ while it is just $10 \%$ for Uzbekistan. For Latin America, Bolivia is about $89 \%$ while Ecuador has a rate of about $20 \%$. The standard deviation in 1996 is 20.5 for the CEE economies, 16.1 for the CIS economies and 29.3 for the Latin American group.

${ }^{2}$ Source: Trim. Report from the BIS (1996-2006)
} 
average, in $2005,30 \%$ of the domestic bank deposits ${ }^{3}$ (and a comparable share of domestic bank loans) in developing economies was foreign denominated (41\% if we exclude economies where dollar deposits are legally banned). The CEE zone is, therefore, a medium-dollarized region and, contrary to some other regions, has globally managed to stabilize its rate of dollarization in the 2000s while none of the countries has ever implemented laws to ban dollar deposits. Nevertheless, some economies, such as Romania and Bulgaria, have undergone hysteresis of their financial dollarization since the financial crisis of 1997 and are today dollarized at about $50 \%$ despite an important macroeconomic stabilization.

If globally the CEE region has performed better with its rates of currency substitution, it is mainly due to their success in stabilizing their economies. The rate of inflation has been drastically reduced from about $360 \%$ in 1992 to $5 \%$ in $2006 .{ }^{4}$ The economic growth volatility has also dramatically decreased for these 11 economies since the standard deviation of the real economic growth went from 6.45 for the 1991-1995 period to 1.09 for the 2001-2005 period. ${ }^{5}$ Finally, the main monetary instrument of the central bank during the initial stages of the transition, the growth of the domestic monetary supply, has also been drastically reduced since the growth of the monetary aggregate M2 went from $34 \%$ in 1995 to $10 \%$ in 2005.

At the same time, we observe in the Central Eastern European economies a political motivation to give more and more legal independence to the central banks in the conduct of the monetary policy. If we take the two main indicators for measuring central bank independence, the one developed by Vittorio Grilli, Donato Masciandaro, and Guido Tabellini (1991) (GMT), and hence called the GMT indicator, and the one by Cukierman (1992), we can observe a very important increase over the first decade of the transition. For the GMT index, the average value of the 11 economies of our sample was about 7 in 1991 and 12.2 in $2003 .{ }^{6}$ This legal independence was so substantial in 1998 that it was even greater than that of the industrial economies in $1988 .^{7}$ However, this substantial legal

\footnotetext{
${ }^{3}$ Source: Banking Report from the World Bank (2006)

${ }^{4}$ Source: Data from the OECD (2007)

${ }^{5}$ Source: Data from the World Bank (2007); The 3 Baltic economies have undergone the most important decrease since the standard deviation has gone from 12.44 for the first period to 1.29 for the second period.

${ }^{6}$ For the same dates, the values of the Cukierman Index were respectively 0.41 and 0.78 .
} 
independence does not protect the monetary authorities from political pressure and we will try to evaluate actual independence.

This raises two, possibly related, questions. First, what are the determinants of the aggregate in foreign currencies? What kind of influence can independent central banks have on the stocks of foreign currencies?

From an institutional point of view, we believe that this model proposes a method to test empirically some of the conclusions of the paper by Cowan and Do (2003), such as the significant impact of a credible central bank on the levels of dollarization. We also confirm the results by Honohan, De Nicolo and Ize (2003), where they find a positive and significant correlation between the share of dollars deposits in total bank deposits and institutional determinants of monetary credibility. From a macroeconomic point of view, the testing of the optimum is consistent with the paper of Rennhack and Nozaki (2006), which finds a positive significant correlation between inflation instability and the dollarization of deposits in Latin America.

The main contribution of this paper is to test the determinants of currency substitution arising from the confrontation between the authorities implementing the monetary policies and the private agents asking for euros and dollars. To build the appropriate monetary policy, we use a time-inconsistency model where the government and the central bank have different priorities. A credible independent conservative central bank seeks to implement a rigorous monetary policy by minimizing the gap between effective monetary growth and what we call potential monetary growth. The main objective of the government is to minimize the output gap. The demands for foreign currencies are built on a simplified portfolio model where both speculative and precautionary motives are taken into account. One of our innovations is to integrate the demand for currencies directly into the dynamics of the exchange rates. Thanks to this original theoretical model, which borrows from literature of time-inconsistency, financial dollarized portfolios and central bank independence, we obtain the optimal aggregate in foreign currencies, and the optimal exchange rates. We then try to test these optima by using some concepts from the literature on central bank independence. Our paper also aims at refining

\footnotetext{
${ }^{7}$ We chose one decade of difference since the concept and the imperative necessity to have an independent central bank started at the beginning of the eighties for the industrial economies when the Eastern European economies were still communist. The dates 1988 and 1998 allow us to have an idea of the situation regarding central bank independence in all the economies eight years after the real initiation of these policies
} 
these empirical analyses by introducing institutional variables like financial development, informal economy, official exchange rate regime and several dummies capturing time-specific and individual-invariant characteristics.

We will show that the introduction of these variables had strong consequences for the dynamics of currency substitution in transition economies.

This paper proceeds as follows. In the next section, we build the general program of minimization. The section II gives the optima of this model and several hypotheses are proposed. The section III provides several measures of the central bank independence. The section IV concentrates on the measures of potential output, inflation instability and other institutional variables. Finally, we test the model econometrically, we comment the results and we conclude.

\section{Hypotheses of the Theoretical Model}

\section{A. The Government}

In our model, we assume that authorities aim at implementing a type of monetary targeting policy whereby the central bank uses monetary aggregates as an intermediate target and a nominal anchor. This policy will allow these authorities to have a better control over inflation. The authority which has the power to modify the money supply directly is the central bank. Concerning the government, it is assumed that it gives a greater priority to minimising the output gap than to the monetary gap. This priority is expressed below by the coefficient $\psi_{t}$ such as $\psi_{t}>1$. The originality of our model is to directly integrate monetary aggregates into the equation. One of the main challenges for these authorities is to be faced with partially dollarized and euroized monetary aggregates. Agents have the possibility to hold foreign currencies.

We then create a model where the authorities have to find a balance between output growth volatility and money supply growth. Policy-makers seek to minimize the following loss function, which represents the preferences of the government in a dollarized and euroized economy:

$$
\operatorname{Min} L_{t}^{g v}=\frac{1}{2}\left(m_{t}^{f o r}+m_{t}^{d o m}-m_{t}^{g l o^{*}}\right)^{2}+\frac{\psi_{t}}{2}\left(y_{t}-y_{t}^{*}\right)^{2}
$$

We know that:

$$
m_{t}^{g l o}=m_{t}^{f o r}+m_{t}^{d o m} \text { and } m_{t}^{g l o^{*}}=m_{t}^{f o r^{*}}+m_{t}^{d o m^{*}}
$$


with $m_{t}^{g l o}$ the general money growth and $m_{t}^{g l 0^{*}}$ the potential general money growth

$$
m_{t}^{f o r}=\frac{M_{t}^{f o r}-M_{t-1}^{f o r}}{M_{t-1}^{g l o}}
$$

with $M_{t}^{\text {for }}$ the stocks of foreign currencies held by domestic residents at the period $t$ and $M_{t-1}^{g l o}$ the global value of all the monetary aggregates at the period $t-1$.

All the variables are variations expressed in real values. We admit the hypothesis in our model that the authorities do not implement laws to restrict strongly the holding of foreign currencies. This restrictive hypothesis is adapted to the 11 transition economies we are studying since, as Levy Yeyati (2006) showed, none have implemented laws to stop or forbid officially the deposits in foreign currencies. ${ }^{8}$ Nevertheless, the theoretical model shows that the authorities aim at limiting as much as possible the growth of dollars and euros in the economy.

On the right side of the above equation, $m r t=m_{t}^{f o r}+m_{t}^{d o m}-m_{t}^{g l o^{*}}$ is called the index of monetary rigor, and is based on the equation of exchange by Fisher (1911). With a stable velocity of money, we have $m_{t}^{\text {gio* }}=y_{t}^{*}$. Because of the absence of a banking system at the beginning of the transition and the very small amount of credits, the monetary aggregate was the only monetary instrument of the authorities in the nineties and is still one of the main ones. If $m r t>0$, then monetary policy may be seen as relaxed and, as the liquidity required by the new transactions is less than the volume provided by the central bank, there is a risk of liquidity overhang. Several papers (Yifan Hu (2003), Brada and Kutan (2003)) empirically showed that monetary aggregate is still a significant determinant of inflation in transition economies, and may support the idea that high inflation is likely to appear with an excess of domestic liquidity. This situation is typical of the beginning of the transition when Central Eastern European economies did not have any banking system and did not have access to international financial markets. Consequently, the only means of financing the state budget was monetary expansion.

If $m r t=0$ then monetary policy is said to be rigorous and does not lead to extra inflation. From now on we use $y_{t}^{*}$ instead of $m_{t}^{g i o^{*}}$.

\footnotetext{
${ }^{8}$ The only restrictions were implemented by Slovak Republic and Hungary but, as shown by Levy Yeyati
} (2006), they were not very important. 


\section{B. The Central Bank}

Suppose now that a "conservative" central banker is put in charge of monetary policy. Conservative means that the central banker is more inflation-averse than the government and, therefore, is more reluctant than the government to expand monetary supply. The loss function of the central bank can, therefore, be written as:

$$
\operatorname{Min} L_{t}^{C B}=\frac{1+\theta_{t}}{2}\left(m_{t}^{\text {for }}+m_{t}^{\text {dom }}-y_{t}^{*}\right)^{2}+\frac{\psi_{t}}{2}\left(y_{t}-y_{t}^{*}\right)^{2}
$$

where $\theta$ denotes the additional inflation aversion of the central banker and his/her willingness not to expand domestic monetary supply, namely his/her conservativeness. The preferences of the central banker do not matter, unless (s)he is able to determine monetary policy. In other words, the central bank should be able to pursue monetary policy without (much) government interference. This can be simply modelled as follows (Eijffinger and Hoeberichts, 1998):

$$
L_{t}^{g l}=\left(1-\delta_{t}\right) L_{t}^{g v}+\delta_{t} L_{t}^{C B}
$$

where $\delta_{t}$ denotes the degree of central bank autonomy, namely to which extent the central banker's loss function affects monetary policy-making. If $\delta_{t}=1$, the central bank fully determines monetary policy. The authorities aim at minimizing:

Min $L_{t}^{g l}=\left(1-\delta_{t}\right) L_{t}^{g v}+\delta_{t} L_{t}^{C B}$, namely $\operatorname{Min} \frac{1+\theta_{t} \delta_{t}}{2}\left(m_{t}^{\text {for }}+m_{t}^{\text {dom }}-y_{t}^{*}\right)^{2}+\frac{\psi_{t}}{2}\left(y_{t}-y_{t}^{*}\right)^{2}$

\section{The Global Program}

At present, we can specify the global program of the authorities:

$$
\begin{gathered}
\operatorname{Min} \frac{1+\theta_{t} \delta_{t}}{2}\left(m_{t}^{f o r}+m_{t}^{\text {dom }}-y_{t}^{*}\right)^{2}+\frac{\psi_{t}}{2}\left(y_{t}-y_{t}^{*}\right)^{2} \\
\text { S/c } y_{t}=m_{t}^{f o r}+m_{t}^{d o m}-m_{t \exp }^{\text {for }}-m_{\text {texp }}^{\text {dom }} \\
m_{t}^{\text {for }}=\left(\frac{\beta\left(1+S_{t d o m}^{2}\right)\left(1-S_{t f o r}^{2}\right) e_{t}}{\left(1+\theta_{t} \delta_{t}\right)^{h}}\right) \text { with } h \in[0 ; 1] \\
e_{t}=m_{t}^{\text {for }}+\left(m_{t}^{\text {dom }}-y_{t}^{*}\right)+\chi_{t}
\end{gathered}
$$

\footnotetext{
$\overline{{ }^{9}} m_{t \exp }^{\text {for }}$ and $m_{t \exp }^{\text {dom }}$ are expected monetary growth respectively in foreign currencies and domestic currency.
} 
With (6), output is driven by a simplified Lucas supply function. ${ }^{9}$

The equation (7) is the agents' reaction function and allows estimation of the dynamic demand for foreign currencies by the private agents. $S_{t d o m}^{2}$ and $S_{t f o r}^{2}$ are the variances of the inflation rates respectively in the domestic economy and in the foreign economy. ${ }^{10} e_{t}$ is the variations of the exchange rates into foreign currencies. The equation is partly inspired by the optimal conditions of Thomas (1985), whose paper has influenced some significant analyses of dollarization (Ize A., and E. Yeyati Levy, (2005)). Currency substitution depends on the inflation instability gap between the domestic economy and the targeted area, namely the United States for the dollar and the European Union for the Euro. As described by Thomas, in that situation, currency substitution is motivated by the need for protection of the savings. If the rate of inflation is very instable (a very high $S_{t d o m}^{2}$ ), then private agents have great difficulty to anticipate coming inflation. If inflation instability of the targeted foreign economy is very low, then they prefer converting their wealth into this foreign currency. Another motive is speculation, private agents asking for euros or dollars in order to make a profit. The key determinant of that type of currency substitution is the exchange rate variation. If $S_{t d o m}^{2}=S_{t f o r}^{2}=0$ then $m_{t}^{f o r}=\left(\beta e_{t}\right)\left(\frac{1}{\left(1+\theta_{t} \delta_{t}\right)^{h}}\right):$ private agents are not compelled to protect their savings from unanticipated inflation but they can ask for dollars and euros for purely speculation motives. The demand for foreign currencies in the economy would just depend on the exchange rates variations, the coefficient $\beta$ and the relative conservativeness and independence of the central bank. The coefficient $\beta$ gives the reactivity of the monetary demand to the macroeconomic determinants. In this function we also added the ratio $\left(\frac{1}{\left(1+\theta_{t} \delta_{t}\right)^{h}}\right)$, which shows that an independent conservative central bank is a sign of credibility of the monetary policy. The power and the willingness of the central bank to reduce inflation reassures the private agents and the need for protecting their savings may be reduced. It also follows from equation (7) that both the independence and the conservativeness of the central bank matter. If the central banker has the same inflation aversion as the government (namely $\theta_{t}=0$ ), then the independence does not matter. And similarly, if the central bank is fully under the spell of the government (namely $\delta_{t}=0$ ), then the conservativeness of the central bank has really fewer impact on individuals' currency portfolio choices. There are various

${ }^{10}$ The foreign economy includes the European Union and the United States. 
combinations of $\delta_{t}$ and $\theta_{t}$ that may yield the same outcome, including the optimal one. Finally, the coefficient $h \in[0 ; 1]$ is the degree of transparency of the decisions taken by the monetary authorities. Perfect information about the independence and the decisions taken by the central bank appears when $h=1$. The degree of independence and conservativeness of the central bank is perfectly known by private agents and the demand for foreign currencies may be considerably reduced. On the contrary if the transparency is null, then $h=0$ and the effect of political capture of the central bank on individuals' currency portfolio choices will be much lower. Provided that $\theta_{t} \cdot \delta_{t}>0$, then better transparency always negatively influences the growth of currency substitution.

The equation (8) shows that the exchange rate depends on the monetary policy implemented by the central bank and a factor $\chi_{t}$. The integration of the factor $\chi_{t}$ assumes that exchange rate may be affected by an external shock. For instance, a monetary restriction in the Euro Area may lead to a positive $\chi_{t}$ and to the depreciation of the domestic currency. Higher currency substitution (positive $m_{t}^{\text {for }}$ ) means that the foreign currencies are preferred to the domestic one and will provoke a depreciation of the exchange rate. Finally the gap between $m_{t}^{d o m}$ and $y_{t}^{*}$ reflects the ability of the monetary authority to conduct rigorous monetary policy.

\section{Optima of the Theoretical Model}

\section{A. Optima}

With rational expectations and minimizing government's loss function, the optima turn out to be:

$$
\begin{gathered}
m_{t o p t}^{\text {for }}=\left(\frac{\psi_{y} y_{t}^{*}}{\left(1+\theta_{t} \delta_{t}\right)^{1+h}}\right)\left(\beta\left(1+S_{t d o m}^{2}\right)\left(1-S_{\text {tfor }}^{2}\right)\right) \\
+\chi_{t} \frac{\left(\beta\left(1+S_{t d o m}^{2}\right)\left(1-S_{t f o r}^{2}\right)\right)}{\left(1+\theta_{t} \delta_{t}\right)^{h}} \\
m_{t o p t}^{\text {dom }}=\left(\frac{\psi_{y} y_{t}^{*}}{\left(1+\theta_{t} \delta_{t}\right)}\right)\left(1-\frac{\beta\left(1+S_{t d o m}^{2}\right)\left(1-S_{t f o r}^{2}\right)}{1+\theta_{t} \delta_{t}^{h}}\right)+y_{t}^{*} \\
-\chi_{t} \frac{\left(\beta\left(1+S_{t d o m}^{2}\right)\left(1-S_{t f o r}^{2}\right)\right)}{\left(1+\theta_{t} \delta_{t}\right)^{h}}
\end{gathered}
$$




$$
\begin{gathered}
e_{t}=\left(\frac{\psi_{t} y_{t}^{*}}{1+\theta_{t} \delta_{t}}\right)+\chi_{t} \\
y_{t}=0
\end{gathered}
$$

It appears that the growth in the stock of foreign currencies positively depends on $y_{t}^{*}, S_{t d o m}^{2}$ and $\psi_{t}$, and is negatively influenced by $S_{t f o r}^{2}, h, \theta_{t}$ and $\delta_{t}$. The growth of the stock of domestic currency positively depends on $y_{t}^{*}, h, S_{t f o r}^{2}$ and and is negatively affected by $S_{t d o m}^{2}, \theta_{t}$ and $\delta_{t}$.

With regard to the independence and the conservativeness of the central bank, we can immediately see that the levels of currency substitution is lower for positive values of $\theta_{t}$ and $\delta_{t}$. In other words, delegating monetary policy to an independent and "conservative" central bank will yield a lower level of currency substitution. There is an optimal level of independence and conservativeness. Ceteris paribus an increase (a decrease) in the bank's conservativeness or independence will lead to a more inflation-averse monetary policy. Conservative independent central banks aim at reducing the monetary gap and provide less dollars and euros. On the demand side, private agents who believe in the credibility of the domestic monetary institutions will ask for less foreign currencies.

It is also important to remember that the transparency $h$ of the decisions of the authorities is a key element of the success of a monetary policy of de-dollarization. As analysed previously perfect information or $h=1$ in our economy will considerably reduce the level of currency substitution as the central bank will be able to directly influence the private agents' portfolio choices. As $m_{t O P t}^{\text {dom }}$ positively depends on $h$, we will observe a transfer from foreign currencies to the domestic one. Otherwise, if $h=0$, then the optimal growth of foreign currencies is much more important and only the supply of foreign currencies can directly influence the dynamics of currency substitution. ${ }^{11}$

The relationship between potential output and dollarization may be ambiguous

\footnotetext{
${ }^{11}$ For instance, in several economies, the deposits in foreign currencies have been declared illegal. The effect is generally counter-productive. This policy has never been adopted by the economies of our sample. However, in 1982, the Mexican authorities obliged Mexican citizens to convert all their dollarized deposits into deposits held in pesos. This monetary policy was a failure, Mexican citizens preferring converting all their domestic dollarized deposits into banknotes and coins or foreign accounts. Mexican banking system was rapidly decreasing and the control of the monetary aggregates was becoming more and more difficult. All these counter-productive effects eventually led the Mexican Central Bank to reauthorize the deposits held in dollars. This example shows that growing transparency of the organization and the decisions of the central bank is a more powerful instrument than banning dollarized deposits. Monetary targeting or inflation targeting are policies which provide complete transparency about the objectives of the central bank, and may help authorities have a better control on currency substitution.
} 
and we will analyze them in the next part. Logically, the demand for foreign currencies positively depend on $S_{t d o m}^{2}$. Here appears the notion of substitutability between the different currencies. This substitutability is all the higher since the services provided by each of these currencies are similar. In an economy where the three main functions (medium of exchange, sore of value, and standard of value) of the domestic currency have been highly dollarized, the coefficient of substitutability may be quite high. Last but not least, whatever the values of $\beta$ may be, the variations of the stocks of foreign currencies negatively depend on $S_{t f o r}^{2}$.

For the equations (11) we can admit that the optimal variation of the exchange rate is dependent on the credibility of the domestic central bank and the monetary policy conducted by the European Central Bank and the Federal Reserve System. As expected, the monetary policy implemented in the euro area and the dollar area may directly affect the value of the domestic currency. More conservative central banks in the United States and in the euro area may lead to a depreciation of the domestic currency.

A credible central bank is a bank which has the willingness to stabilize the exchange rates and the monetary gap we previously described. It also needs to be independent enough to implement its own monetary policy. The equation (11) clearly shows that one of the implicit objectives of a conservative and independent central bank is to stabilize the exchange rates. This optimum means that exchange rate is an endogenous variable which can be corrected by a conservative independent central bank.

Even if they were not directly integrated into the theoretical model, the exchange rate regimes may play a role in the dynamics of currency substitution. As the demand for dollars and euros caused by the motive of speculation is directly connected to exchange rate variations, lower exchange rate variations may lead to lower currency substitution. We will integrate a dummy in our econometric test to estimate the impact of these official fixed exchange rate regimes on the level of currency substitution. The idea is to determine if the implementation of harder pegs reassures private agents.

\section{B. Hypotheses}

From now on, we can use some hypotheses which will help us econometrically test the optimum $m_{t O p t}^{\text {for }}$. High potential economic growth could be the source of increasing confidence of the agents into their economy. Bright prospects may reassure private agents whose precautionary motives to dollarize their savings are 
declining. The evolution of the statistics of the studied economies generally confirms this view. ${ }^{12}$

Nevertheless, for some economies we could observe stagnation of currency substitution, and increasing economic growth. This hysteresis of dollarization, which occurred in Croatia, Romania and Bulgaria after the financial crisis of 1997, is usually explained by a loss of confidence of private agents in the ability of their monetary authorities to stabilise the economy over a long term. When this kind of economic process appears, macroeconomic variables have very little influence on dollarization. Concerning the government's weight on output stabilization, we assume that it has a negative influence on the variations of the stocks of foreign currencies. A high willingness of the government to reduce the output gap may lead to lower uncertainty concerning expected real output growth and then private agents feel more comfortable and do not need systematically to protect their savings. Consequently, with $y_{t}{ }^{*-}=\left(-y_{t}^{*}\right)$ and $\psi^{-}=(-\psi)$, we have $y_{t}^{*-} \psi^{-}=y_{t}^{*} \psi$. This shows the negative influence of both the potential output and the government's weight on output stabilization on dollarization.

Then, we admit that $\chi_{t}=0$. From an economic point of view, this restriction means that the exchange rate variation depends only on the conservativeness of the central bank, the monetary gap and the changes in supply of and demand for the domestic currency and the foreign ones.

Concerning $S_{\text {tfor }}^{2}$ we suggest an approach to the empirical specification, in which foreign prices are constant: $S_{t f o r}^{2}=0$. Although this restrictive hypothesis does not allow us to test the substitutability between the currencies of the model, the substantial difference between domestic values and European and American values of inflation instability may support this restrictive hypothesis. Concerning the transparency $h$, despite the fact that it may work in theory, from a practical point the concept of transparency is very difficult to be measured. To simplify our empirical analyses we will admit that $h=0$. In that case, we can estimate:

\footnotetext{
${ }^{12}$ If we exclude Romania, Bulgaria and Croatia, the average of the real economic growth of these 8 economies was about $1.2 \%$ in 1996 while the rate of currency substitution was $17.1 \%$. For 2004, we respectively have $4.3 \%$ and $12.1 \%$. In the case of Romania, Bulgaria and Croatia, the potential influence of output growth may be also present as during their severe recessions at the time of the 1997 crisis these three economies all underwent substantial acceleration of the rate of dollarization.
} 


$$
m_{t O p t}^{f o r}=\left(\frac{\psi_{t} y_{t}^{*}}{1+\theta_{t} \delta_{t}}\right) \varphi_{t}^{g l o} \text { with } \varphi_{t}^{g l o}=\left(\beta\left(1+S_{t d o m}^{2}\right)\right)
$$

The influence of the domestic inflation instability will be measured through the function $\ln \left(\varphi_{t}^{\text {glo }}\right)$.

From now on, we can use the logarithm function to estimate econometrically the equation (14). We then obtain:

$$
\ln m_{t O p t}^{g l o}=\ln \psi^{-}+\ln y_{t}^{*_{-}}-\ln \left(1+\delta_{t} \theta_{t}\right)+\ln \left(\varphi_{t}^{g l o}\right)+\eta_{t}
$$

where $\eta_{t}$ is random shock with zero mean and variance $\sigma_{\varepsilon}^{2}$.

\section{Measures of the Independence and Conservativeness of the Central Bank}

\section{A. Legal Independence}

The construction of so-called legal indicators is done by structuring those criteria, which are regarded as being relevant and valuating the compliance with them on a numerical scale. Legal indicators are used as noisy indicators of actual central bank independence. Because the legal foundations of monetary policies in most economies change relatively rarely, legal indicators possess practically no explanatory power for the economic development within economies. Most of the empirical studies on the relationships between central bank independence and macroeconomic performance are, therefore, cross-sectional (Cukierman (2000), De Haan et al. (1996), Maliszewski (2000), Jacome and Vazquez (2005)). Evaluation of central bank laws is done by calculation of numerical index values. These values are used to rank central banks in accordance with their independence.

Many econometric studies go beyond a purely ordinal aspect because they use the numerical values of indices as explanatory variables in econometric regressions. It is, therefore, particularly important to know how the legal measures for central bank independence also differ with regard to their numerical index values. Primarily, there are three problem areas, which have led to different index values in the literature. The index values are dependent on (Mangano (1998)):

(1) the criteria contained in the index;

(2) the interpretation and evaluation of the law with regard to each individual criterion; 
(3) the way in which evaluations are aggregated into an overall index, including the weighting of the criteria.

These problems make it clear that the construction of indexes for measuring central bank independence inevitably contains subjective and arbitrary aspects (Eijffinger and Schaling (1993), Mangano (1998), Cukierman Webb and Neypati (1992)). In the following, some frequently used indexes are introduced and compared with each other.

The two main legal indexes are the Grilli Masciandaro Tabellini Index (GMT) (1991) and the Cukierman Index (1992).

The GMT index is composed of two sub-indices, defined as political and economic independence of the central bank. The concept of political independence comprises nine sub-items covering appointment procedures for the members of the central bank's highest decision-making body, the relationship between this body and the government and the formal responsibilities assigned to the central bank. The economic independence of the central bank is composed of seven sub-items, which include the issue of central bank financing of the budget as well as the nature of monetary instruments. Every sub-item is scored using a binary system under which the figure one is either assigned or not assigned. The overall index of legal CBI is obtained by a simple addition of unweighted scores on political and economic independence.

The Cukierman index (1992) comprises 16 sub-items for assessing the degree of legal CBI, which are grouped into the following four sets of items: 1) Variables on the status of the governor, namely his term of office, appointment and dismissal procedures and incompatibility clauses; 2) the policy formulation variables, comprising regulations on the competence to formulate monetary policy, the central bank's potential participation in the budget process as well as regulations on potential conflicts between the central bank and the government; 3) the legislated central bank objectives; and 4) regulations concerning limitations of lending. Each of the sixteen sub-items is assigned a score between 0 (lowest) and 1 (highest level of independence), where the „fine tuning” for each sub-score depends on the legal alternatives proposed by Cukierman. The overall index for each country is obtained in two different ways, either by calculating an unweighted mean (LVAU) or by computing a weighted index (LVAW). In contrast to Grilli, Masciandaro and Tabellini (1991), graded evaluations are provided for with detailed questions as well.

The table in annex 2 gives the value of each index for each country of our panel. 
The values for industrial economies are those for 1988 while, for transition economies, they are from 1998. We chose one decade of difference since the concept and the imperative necessity to have an independent central bank established at the beginning of the eighties for the industrial economies when the Eastern European economies were still communist. The dates 1988 and 1998 allow us to have an idea of the situation regarding central bank independence in all the economies eight years after the real start of these policies. Using the two indexes, we note that, on average, aggregate legal independence of new central banks in transition economies is substantially higher than legal CBI in developed economies. Actually, the average of the Cukierman Index is 0.38 for the industrial economies in 1988 and 0.63 for the transition economies in 1998, while as regards the GMT Index the average is respectively 8.33 and 12.54 . The annex 3 provides us with the evolution of this legal independence among our eleven economies. The table shows that legal independence is time varying and mainly depends on the new rules and legislation implemented by the political authorities.

\section{B. Actual Independence}

Whatever the interpretation of the new laws may be, in our opinion there is another important problem concerning these laws. Are they really implemented? Here appears the gap between actual independence and legal independence. Several authors have tried to measure actual independence. To do so, they created indicators based on actual behaviour. For instance, Cukierman (1992) and Cukierman/Webb/Neypati (1992) calculated the actual turnover rates for central bank governors for the period 1950-1989. This indicator is based on the assumption that a higher frequency of change of central bank governors indicates a lower level of central bank independence. For them, on the one hand, a longer term does not necessarily imply greater independence but, on the other hand, if the terms of office served are shorter than the electoral cycle, this can lead to the suspicion of lack of personal independence. However, this interesting indicator cannot be used for the transition economies since at present the period studied is not long enough to obtain efficient tests.

It is consequently better to adopt another indicator for the transition economies. Alpanda and Honig (2008) examine the extent to which monetary policy is manipulated for political purposes by testing for the presence of political monetary cycles between 1972 and 2001 in a large sample of countries. In their regressions between M1 growth and several variables, they use a ranking of the actual CBI 
which is based on the behaviour of central banks during election cycles when their independence is likely to be challenged. Their results show evidence of political monetary cycles only in developing economies. While the authors integrated transition economies directly in their regression, we do not think the period of free political elections of these countries has been long enough to use such a ranking of the actual CBI.

Lougani and Sheets (1997) examine the influence of central banks' legal independence on the inflation rates in 1993 for a group of twelve economies. The study comes to the conclusion that there is a highly negative correlation between central bank independence and inflation, even after controlling for other factors, such as fiscal balance, reform index and the average tenure of central bank chairman (Lougani and Sheets (1997)). However, the concentration on the inflation rates for a single year, and the fact that many of the central bank statutes, which were examined, had not been in force for very long, give rise to doubts regarding the robustness of the Lougani and Sheets findings.

For example, Eijffinger and Keulen (1995) find no significant relationship between central bank independence and inflation for a total sample of eleven economies (including three transition economies: Hungary, Poland and Czech Republic), but they show that there is a negative relationship between central bank independence (measured with the GMT indicator) and inflation for those six economies where the central bank has been functioning for more than five years. It seems that it takes at least five years for these economies to implement the change of the statute of their central bank efficiently. We can, therefore create an indicator of actual independence, which takes this vital period of implementation into account. The indicator and the scores developed by Maliszewski (2000) and extended by Arnone, Laurens and Segalotto (2006) for several economies, and mainly based on the GMT methodology, can be turned into a progressive indicator, whose value each year is equivalent to the sum of the value of the previous year and twenty percent of the gap between the new value of the CBI which has been adopted by the politicians, and the value of the previous year.

Our progressive indicator can include both the $\mathrm{CBI}$ and the institutional progress of each country. It is an actual index since it takes the behaviour of the authorities into account, their abilities (or inabilities) to implement the laws which have been voted by the Parliament. This index has two main advantages for a panel estimation. Firstly, it allows us to have a value of this progress for each year of each country and, consequently, increases the precision of our panel by avoiding 
the problems of "explosions" between each period. Secondly it provides us with an average period of a good implementation of the functioning of the central bank. Of course, this average is not the value for all the economies but with a panel of 11 economies we can obtain very good results with this criterion since the economies may all score around this average.

\section{Conservativeness of the Central Bank}

Despite the fact that it may work in theory, from a practical point the concept of a "conservative" central bank seems void, if only since the preferences of possible candidates for positions in the governing board of a central bank are generally not very easy to identify and may change after they have been appointed. So, it is hard to identify the real world of a "conservative" central banker. We can also argue that the statutes of the central bank can be relevant here, especially with respect to the description of the primary goal of monetary policy. We will, therefore, use an index, which can be assimilated to the legal conservativeness of the monetary authorities, actual conservativeness being clearly too difficult to be measured. A situation where the statutes of a central bank define price stability as the primary policy goal, can be considered as a proxy for the "conservative bias" of the central bank as embodied in the law (Cukierman (1992)). In the table in annex 3, this is included in the criterion $\mathrm{C} 8$, which stipulates that there is a statutory responsibility to pursue monetary policy. We can note, with regard to this table, that all the reforms of the central banks in the transition economies have adopted this statutory responsibility. We can, therefore, legitimately admit that $\theta=1$ since the conservatism of the governing board of the central bank is logically superior to the one of the government even if this board can sometimes be subject to some pressure from the politicians. Moreover, if we admit that $\theta=0$, then neither the independence nor the conservativeness of the central bank can influence the rate of inflation. Except in extreme situations, this hypothesis is too restrictive.

\section{Data, Econometric Tests and Interpretation}

\section{A. Data}

Regarding the monetary phenomena of currency substitution will use the ratio which integrates the increase of the deposits in foreign currencies (checkable deposits and currency time and savings deposits, both in euros or dollars) for the 
numerator, and the aggregate M2 of the previous period (local checkable deposits and local currency time and savings deposits) with the deposits in foreign currencies for the denominator. In early literature, some authors, Cuddington (1983) and Thomas (1985), divided dollarization into two phenomena: currency substitution and asset substitution. The first one is related to the holding of foreign currencies under the form of cash, while the second one is linked with deposits. As it is almost impossible to estimate the amount of foreign cash in circulation outside the banking system, we will not include it in our time series. ${ }^{13}$ Annex 4 provides the periods for which we have complete data. All these data come from the Central Banks of the 11 tested economies. Before 2002, instead of using the euro we take Austrian schilling, Belgian franc, Dutch guilder, Finnish markka, French franc, German mark, Irish pound, Italian lira, Luxembourg franc, Portuguese escudo, Spanish peseta and Greek drachma. As our tests concern the period before 2007, we do not take into account the integration of Slovenian tolar, Cypriot pound, Maltese lira and Slovak koruna into the European Monetary Union III

The standard deviation of the domestic inflation is measured on a yearly basis. For each year we calculate the deviations of the monthly inflation rate from the yearly average.

To measure potential output in a transition economy, we will use the Hodrick Prescott filter Approach (HP Filter). This methodology calculates the long-term tendency by using only observable date. The tendency is obtained by minimizing fluctuations of actual data around the trend. As did Benes and N'Diaye (2004), we consequently minimize the following function:

$$
\sum\left(\ln y_{t}-\ln y_{t}^{*}\right)^{2}+\lambda \sum\left(\left(\ln y_{t+1}^{*}-\ln y_{t}^{*}\right)-\left(\ln y_{t}^{*}-\ln y_{t+1}^{*}\right)\right)^{2}
$$

where $y_{t}^{*}$ is the trend of the variable $\mathrm{y}$ or its long-term tendency.

The coefficient $\lambda$ in function (11) regulates how smooth the long-term GDP tendency (which can be interpreted as potential output in this case) is. A low $\lambda$ value gives a trend that follows closely the movements in actual GDP, while a high $\lambda$ value reduces the sensitivity of the trend to short-term fluctuations. If the value of $\lambda$ is very high, the long-term tendency obtained by the HP filter is similar to the linear trend. The $\lambda$ value for the HP filter can often be selected freely depending on the desirable smoothness of the final trend. It is common practice to select a $\lambda$

${ }^{13}$ For a measurement of the amount of foreign currency in circulation, see Feige and Dean (2002). 
value from 100 to 10 for annual data. When the trends obtained with different $\lambda$ values are compared, one can see that higher $\lambda$ values increase the difference between the actual and smoothed time series. The HP filter approach has two positive features. Firstly, the trend obtained is influenced by shocks. Secondly, it is simple to measure, hence also to reproduce. On the other hand, the method also has a number of drawbacks. The HP filter produces a good result only when data on a stable economic environment are not affected by strong shocks. In this case, the HP filter and econometric methods have an advantage over a simple linear trend. However, several shocks did affect growth in some economies of our panel, as in Bulgaria and Romania in 1997, and substantial and accelerated changes in actual output do not necessarily signal either expansion or contraction of potential output. In this context, reliance on the HP filter approach alone may lead to erroneous assumptions. In addition, sources often criticise elements of the HP filter such as the freedom to select the $\lambda$ value and biases at the ends of the time series that may influence the economic policymakers' decisions. Irrespective of the given drawbacks, the HP filter approach is widely employed because of its simplicity. We estimate it for the 11 countries. We can observe that many values of this potential output have been positive so $y_{t}^{*-}<0$. Moreover, as the government's weight on output stabilization is positive, we will have $\psi^{-}<0$. Consequently, as most authors do in such a situation, we will use a semi-logarithmic function in order to use all the data provided by the central banks of the 11 countries. We will estimate the below function ${ }^{14}$ :

$$
\left(m_{t O p t}^{g l o}\right)_{\log }=\psi^{-}+y_{t}^{*-}-\left(1+\delta_{t}\right)_{\log }+\left(\varphi_{t}^{g l o}\right)_{\log }+\eta_{t}
$$

where $\left(1+\delta_{t}\right)_{\log }=\ln \left(1+\delta_{t}\right) ;\left(\varphi_{t}^{g l o}\right)_{\log }=\ln \left(\varphi_{t}^{g l o}\right)$ and $\left(m_{t O p t}^{g l o}\right)_{\log }=\ln \left(m_{t O p t}^{g l o}\right)$

To complete the analysis, we will add three other factors to the function (15): the development of the banking system, the importance of the informal sector, and the impact of the official exchange rate regimes.

De Freitas (2004) and Feige and Dean (2002) underlined the importance of under-developed financial markets and informal sector into the growth of the stocks of foreign currencies. As for most authors (Vetlov (2001)), a growing banking sector leads to a decrease in the stocks of foreign currencies. Actually, this

\footnotetext{
${ }^{14}$ This semi-logarithmic function has been used by Piontkiwsky (2002) in his empirical studies in order to use all the provided data.
} 
financial development means a change in the characteristics of the optimal portfolio. The growing number of financial products into the domestic currency, such as state bonds, allows better diversification of the risks. A better banking system could protect private agents from the risks linked to inflation by creating bonds in domestic currency, which are correlated with the rate of inflation. Inflation instability has fewer negative consequences and dollarization decreases. ${ }^{15}$

In order to measure the development of financial markets, the most commonly used indexes are the currency in circulation to GDP ratio, the deposit to Total Liability ratio, M2 to GDP ratio and private domestic credit to GDP ratio (Jalil and Ma (2008)). As our tested variables are linked with deposits and monetary aggregates, we will use the private domestic credit to GDP ratio to avoid problems of correlation. Then, we will integrate into our tests the ratio $(F M D)_{t}=\frac{(\text { Private_Domestic_Credits })}{(\text { Real_GDP })_{t}}$, the values of which are also provided by the central banks of each ${ }^{t}$ country.

The Informal sector refers to all productive economic activities that fall outside the formal economy regulated by the State. In our view, this informal sector has a positive influence on the demand for dollars or euros. Feige, Sosic, Faulend, and Sonje (2001) showed that the use of foreign currencies allows dissimulation of some financial transactions. The evolution of the informal sector is measured with the ratio $(I S)_{t}=\frac{(L C C)_{t}}{\left(M_{2}\right)_{t}}$, where LCC is the volume of the Local Currency into circulation. As for Schneider and Frey (2000), this is the most pertinent ratio when we test correlations. Higher values for this ratio mean that more transactions are paid in cash. The declaration of transactions paid in cash often depends on the sincerity of the private agents. Undeclared transactions require cash and can be linked to illegal activities.

Finally the choice of the exchange rate regime ers $s_{t}$ may have an impact on the motive of speculation. Credible hard pegs mean stability of the domestic exchange rate and may reduce the demand for dollars and euros. Most of the Eastern-

\footnotetext{
${ }^{15}$ However, as for Feige and Dean (2002), the development of the banking system will lead to an increase in deposits in euros and dollars. At the beginning of the transition, the absence of the banking system compelled private agents to turn their wealth into foreign bank notes. Then, more efficient banks created banking products such as deposits into foreign currencies and private agents preferred converting their cash. At the same time, for some economies, the author found negative correlations between the volume of deposits into foreign currencies and the volume of deposits into the domestic currency. To determine which of these two effects is the greater, namely to know if the transfer from FCD (foreign currencies deposits) to LCD (local currency deposits) is superior to the transfer from FCC (foreign currencies cash) to FCD, Feige and Dean proposed to analyze case by case.
} 
European Economies have adopted more or less flexible exchange rates systems. The only economies to have officially adopted hard pegs are Bulgaria (linked to the euro since 1997 while, before it had a flexible exchange rate regime), Latvia (pegged to the SDR from 1994 to 2004 and pegged to the euro with a fluctuation band of $\pm 1 \%$ since $2005^{16}$ ), Lithuania (pegged to the dollar from 1994 to 2002 and pegged to the euro since 2002) and Estonia (linked to the Deutsch Mark from 1992 to 1999 and linked to the euro since 1999). The credibility of these regimes has been seriously tested since the beginning of the financial crisis at the end of 2008 . The choices made by the other economies are summarized in the annex 6 . The more rigid is the announced exchange rate regime, the bigger is the assigned figure. The sign of the coefficient related to this exogenous variable is ambiguous. If these regimes are seen as credible by private agents, then harder pegs may lead to lower levels of currency substitution. But the absence of credibility of such regimes may have contrary effects on the growth of dollars and euros inside the economy. Worse, the adoption of a hard peg may reveal to the private agents the inability of the monetary authorities to stabilize the economy.

\section{B. Econometric Tests}

\section{(1) Problems of Endogeneity}

At present we check the consistency of our regression and we will try to exclude the problems of endogeneity. We will test if inflation instability and informal economy are endogenous variables.

The idea that inflation instability could be an endogenous variable comes from Maliszewski (2000) and Levy Yeyati (2006). The first of the two authors regressed central bank independence on the rate of inflation in transition economies and finds, with several hypotheses concerning the institutional evolution of these economies, a significant negative relation between the two variables. Levy Yeyati studied the consequences of currency substitution on the rate of inflation and finds a positive significant relation. Both authors use the rate of inflation while, in our analysis, we focus more on the instability of this variable. However the value of inflation and its variability may be correlated and that is why we will perform a Durbin-Wu-Hausman test as follows:

$$
\left(\varphi_{t}^{g l o}\right)_{\log }=\alpha_{1}+\alpha_{2}\left(m_{t o p t}^{g l o}\right)_{\log }+\alpha_{3}\left(1+\delta_{t}\right)_{\log }+\alpha_{4} B C L I_{t}+\alpha_{5} y_{t}{ }^{{ }_{-}}+\phi_{t}
$$

\footnotetext{
${ }^{16}$ SDR: Special Drawing Rights
} 


$$
\begin{aligned}
\left(m_{t O p t}^{g l o}\right)_{\log }= & \alpha_{7}+\alpha_{8} y_{t}^{{ }^{*}-}+\alpha_{9}\left(1+\delta_{t}\right)_{\log }+\alpha_{10}\left(\varphi_{t}^{g l o}\right)_{\log } \\
& +\alpha_{11}\left(F M D_{t}\right)_{\log }+\alpha_{12} e s_{t}+\alpha_{13}\left(\varphi_{t}^{g l o}\right)_{\log }^{r e s}+l_{t}
\end{aligned}
$$

The auxiliary equation (17) tests the determinants of the inflation instability. As previously analyzed, we included central bank independence and currency substitution into the list of the determinants. The effect of the official exchange rate regime on inflation instability might be ambiguous. If the main objective is to stabilize exchange rate, then prices can be the only variable to stabilize the real exchange rate. Harder pegs could lead to more inflation instability. The variable $B C L I_{t}$ is linked to the Cumulative Liberalisation Index (De Melo et al. (1996)), usually called the CLI. The authors constructed annual liberalization indices assessing transition economies progress in three areas, liberalization of the internal markets, liberalization of the external markets, privatization and restructuring, between 1989 and 1994. These indices were then used to construct the measure of CLI, defined as the sum of yearly weighted-average indices (with weights $0.3,0.3$ and 0.4 , respectively). Using the CLI as an explanatory variable for economic performance, they found that greater liberalization was associated with higher growth and lower inflation (both averaged over 1993-94). We will admit that our variable $B C L I$ is equal to 0 if $C L I<2$ and 1 if $C L I>2$. The threshold of 2 has been chosen by Cukierman et al. (2000) and means that the transition economy has taken the first step of its transition. Once the economy is beyond 2 we logically assume that, up to 2007, it has never come back below this threshold.

Eventually the potential economic growth could bring about more inflation as it is often the case in countries with fast growing economies.

The initial equation of interest $(23)$ regress $y_{t}^{{ }^{*}-},\left(1+\delta_{t}\right)_{\log },\left(\varphi_{t}^{g l o}\right)_{\log }$, $\left(F M D_{t}\right)_{\log }, e r s_{t}$ and $\left(\varphi_{t}^{g l o}\right)_{\log }^{\text {res }}$ on $\left(m_{t O p t}^{\text {glo }}\right)\left(\varphi_{t}^{\text {glo }}\right)_{\log }^{\text {res }}$ are the residuals of the auxiliary equation. As we have doubts regarding the exogeneity of the variable capturing the effects of informal economy, we exclude this variable from the regression (18). If $\delta_{t}$ is measured with legal central bank independence, then the $p$-value provided by the Durbin-Wu-Hausman test shows that the risk to reject the null hypothesis by mistake is $21.5 \%$. With actual central bank independence the risk is $16.5 \%$. We are then allowed to conclude that our OLS is consistent. 
The variable $I S_{t}=\frac{(L C C)_{t}}{\left(M_{2}\right)_{t}}$ is also likely to be endogenous. As currency substitution is measured with $\frac{m_{t}^{\text {for }}}{m_{t-q}^{g l o}} 17$, there is a potential problem of simultaneity.

We will then regress the level of currency substitution on IS.

$$
\begin{gathered}
\left(I S_{t}\right)_{\log }=\alpha_{14}+\alpha_{15}\left(m_{t O p y}^{\text {glo }}\right)_{\log }+\alpha_{16}\left(1+\delta_{t}\right)_{\log }+\alpha_{17} B C L I_{t} \\
+\alpha_{18}\left(F M D_{t}\right)_{\log }+\alpha_{19} y_{t}^{*-}+\zeta_{t} \\
\left(m_{\text {topy }}^{\text {glo }}\right)_{\log }=\text { Left }_{t}+\alpha_{26}\left(I S_{t}\right)_{\log }+\alpha_{27}\left(I S_{t}\right)_{\log }^{\text {res }}+\diamond_{t}
\end{gathered}
$$

where Left $_{t}=\alpha_{20}+\alpha_{21} y_{t}^{{ }^{*}-}+\alpha_{22}\left(1+\delta_{t}\right)_{\log }+\alpha_{23}\left(\varphi_{t}^{\text {glo }}\right)+\alpha_{24}\left(F M D_{t}\right)_{\log }+\alpha_{25}$ ers $_{t}$

The determinants of $\left(I S_{t}\right)_{\log }$ are multiple. As the external shock of the transition strongly affected the institutions of the Central and Eastern Europe, the disorder of the beginning of the nineties may have caused more and more informal transactions. To capture the phenomenon of progressive liberalization, we integrated the variable $B C L I_{t}$ into the auxiliary equation (19). The independence of the central bank may have a negative impact on the growth of $\left(M_{2}\right)_{t}$. The effects of the development of the banking system captured by $\left(F M D_{t}\right)_{\text {log }}$ means that more efficient banking products and services are provided to the private agents. Consequently these agents can progressively convert their coins and banknotes into more elaborate deposits. Finally the enrichment of the economy, measured by the potential economic growth $y_{t}^{*-}$, helps more and more people to earn their own living without having informal business.

The Durbin-Wu-Hausman test shows that the risk to reject the null hypothesis by mistake is $1.56 \%$ with legal central bank independence and $0.02 \%$ with actual central bank independence. The OLS is not consistent and one of the solutions is to find another variable which is able to capture the effects of informal economy without being correlated to the error term of the initial equation of interest. Measuring corruption may be a solution.

One of the main indicators for the evaluation of corruption has been annually published by Amnesty International since 1995. This indicator commonly named Corruption Perceptions Index, orders the countries of the world according to the degree to which corruption is perceived to exist among public officials and politicians. The organization defines corruption as "the abuse of entrusted power for private gain". This index is scaled from 0 (most corrupt) to 9 (least corrupt). It

\footnotetext{
${ }^{17}$ With the low development of the banking system in the economies of our panel we could even emit the hypothesis that $m_{t-1}^{g l o} \cong\left(M_{2}\right)_{t}$
} 
is an average of ten survey results on corruption over several years. The lack of standardization and precision in these surveys is sometimes cause for concern. However it is regularly used by pundits and researchers (Shang-Jin (2000)).

(2) Legal Central Bank Independence or Actual Central Bank Independence? In this section, we will econometrically test the following function, based on (15):

$$
\begin{gathered}
\left(m_{t o p y}^{g l o}\right)_{\log }=\alpha_{28}+\alpha_{29}\left(1+\delta_{t}\right)_{\log }+\alpha_{30}\left(\varphi_{t}^{g l o}\right)_{\log }+\alpha_{31} y_{t}^{*-} \\
+\alpha_{32}\left(F M D_{t}\right)_{\log }+\alpha_{33} \log \left(C O R_{t}\right)_{\log }+\alpha_{34} e s_{t}+\eta_{t}
\end{gathered}
$$

where we anticipate: $\alpha_{29}<0, \alpha_{30}<0, \alpha_{31}<0, \alpha_{32}<0$ and $\alpha_{33}>0$.

In annex 5, we use EViews 3.1 to estimate the coefficients $\beta$. For the estimation of our panel data we use Stata 8.0.

Since results from the panel data are sensitive to estimation methods, we adopt two approaches. The first one, usually called one-way component regression model, is based on a model including only individual effects. The second approach, the two-way component regression model, is a model where each individual and time period has different specific parameters. The significance of individual and time effects is tested by F-tests. For each approach we also build regressions with fixed and random effects. The Hausman (1979) specification test evaluates the significance of random effects versus fixed effects.

The results of the Table 1 lead us to several conclusions. First of all the results clearly show that the index of progressive central bank independence (actual central bank independence) has more influence than that of classical central bank independence (legal central bank independence). It is, therefore, advisable to integrate a period of implementation of the new laws and rules when we want to determine the impact of legal central bank independence on macroeconomic variables. Whatever the choice of portfolio the private agents may have made, a highly autonomous central bank has direct influence on the growth of the deposits in foreign currencies. This could mean that independent central banks have low currency substitution as one of their main implicit objectives.

If we keep only the regressions with the index of actual central bank independence, the model with individual effects is preferred to the model with both individual and time effects (on the basis of the values provided by the F-test). The Hausman test shows that fixed effects are superior in terms of efficiency to random effects. This is partly due to the diversity of the macroeconomic situations of 
Table 1. Determination of the More Powerful Determinant: Legal Central Bank Independence or Actual Central Bank Independence?

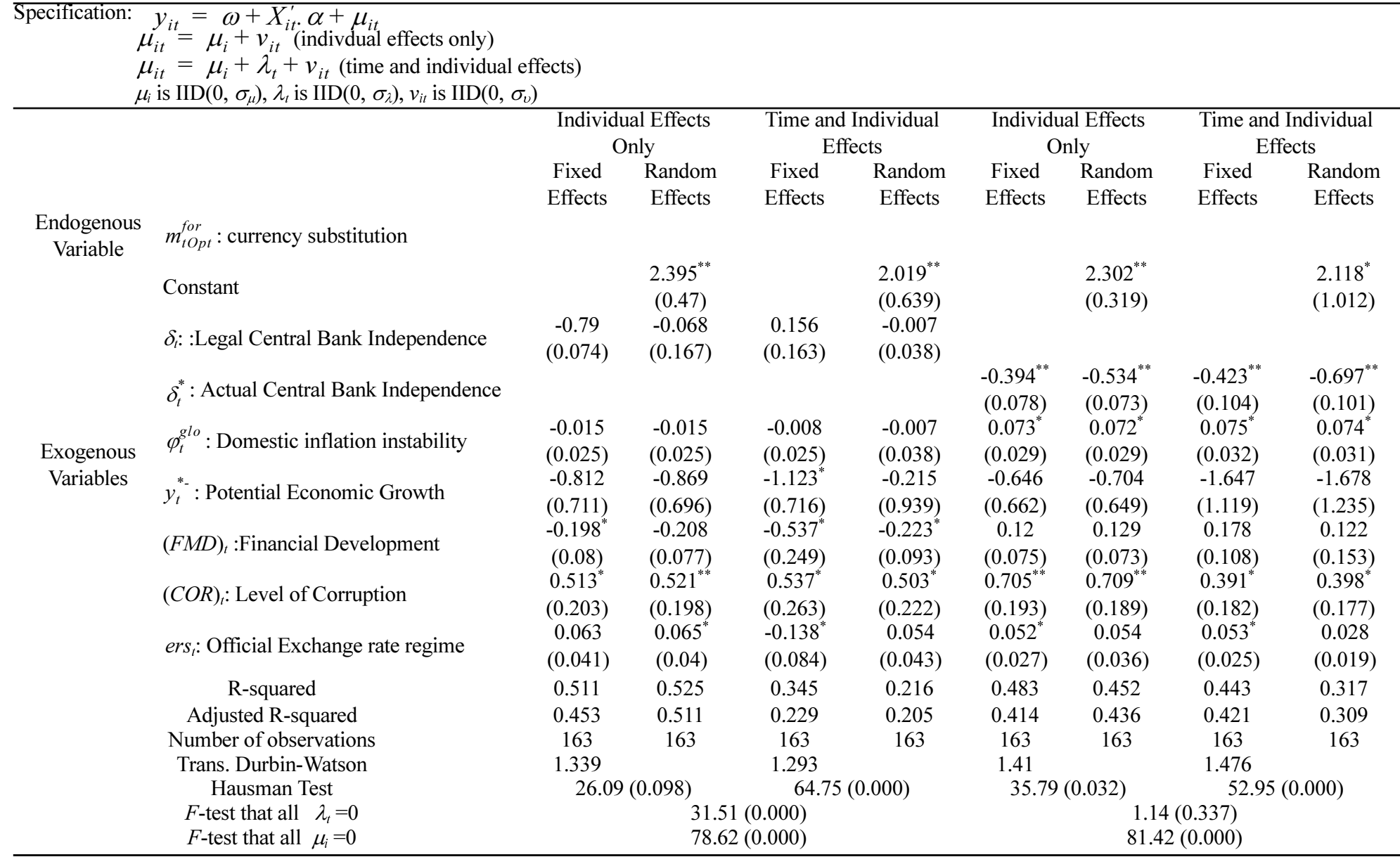

Notes: Numbers in parenthesis under coefficients are standard errors.

** and $*$ denotes significance at $1 \%$ and $5 \%$ respectively.

The "Trans. Durbin Watson" value is the one after performing a Cochrane-Orcutt estimation. 
several economies of our panel. For instance, in Romania, Bulgaria, Lithuania and Croatia, currency substitution is much higher at the beginning of the 2000's than in the other economies; and the financial and monetary crisis of 1997 was somewhat more important in Romania and Bulgaria than in the other economies of our panel.

As expected, informal sector and domestic inflation instability both have positive influence on the stocks of foreign currencies, while central bank independence and potential output negatively influence dollarization. With progressive central bank independence and five per cent of significance level, inflation instability is a significant variable. This result is consistent with the empirical literature about the macroeconomic determinants of currency substitution, and proves that the precautionary motive may be a key element of currency substitution. However, with one per cent of significance level, inflation instability is rejected. Informal economy, actual central bank independence and official exchange rate regimes all have significant influence on the dynamics of dollarization. Financial development does not seem to affect the level of currency substitution.

Fourth, the positive sign of the official exchange rate regimes means that, in general, harder pegs fail to inverse the growth of currency substitution in Central and Eastern European Economies. These pegs clearly lack credibility since more rigid regimes lead to more currency substitution. The implementation of harder pegs may reveal to the private agents the inability of the monetary authorities to stabilize the economy. As described previously, Bulgaria, Estonia, Latvia and Lithuania were the only ones to adopt currency boards, and each time this choice was made in extreme circumstances. Deep financial crisis and higher macroeconomic volatility lead these economies to give up their monetary sovereignty. This decision may have been seen as a sign of extreme weakness by private agents. Before these econometric results, we expected an impact of the official exchange rate regimes only on the speculation motive. The motive of protection of savings could also have been affected by theses changes of pegs.

Finally, potential output does not influence currency substitution. Apparently good prospects in terms of economic growth do not influence currency substitution. According to our results the main factors of currency substitution are then essentially financial and institutional.

\section{(3) "Successful" and "Unsuccessful" Samples}

At present we introduce three different samples. The first one is the overall 
sample with the eleven economies. We also study the "successful" sample, which is composed of the eight economies which integrated the European Union in 2004, namely Czech Republic, Estonia, Hungary, Latvia, Lithuania, Poland, Slovakia and Slovenia. Eventually we will analyze the "unsuccessful" sample, which is composed of Bulgaria, Croatia and Romania. The idea of success is mainly based on the ability of each economy to reduce their rates of currency substitution.

To capture the time-specific and individual-invariant characteristics we integrate two dummies. One valorises the presence of strong overall external shocks which can deeply affect all the economies of our panel at the same time. This dummy includes both the unbalanced beginning of transition and the Asian crisis of 1997, which led Russia, Ukraine, Bulgaria and Romania to be close to bankruptcy. The initial period of the transition is a period of important imbalances due to the change of political and economic system for our 11 economies. Unfortunately the absence of complete data for the other variables does not allow us to study the impact of the beginning of the transition on currency substitution. The dummy $(\text { Crisis })_{t}$ is equal to 1 for the years 1997, 1998, 1999 and 2000, at the worst moment of the international monetary and financial crisis, and to 0 for all the other years. To avoid potential correlation between macroeconomic volatility and crisis, we will exclude the variables inflation instability and potential growth when we take the dummy crisis into account.

The other dummy $(\text { in })_{t}$ captures the effects of the integration of these economies into the European Union. Eight economies out of eleven integrated the European Union on the 1 May, 2004. We will study the impact of this dummy only on this restricted panel by assigning 0 to the years before 2004 and 1 afterwards. The integration of Romania and Bulgaria took place at the beginning of 2007 while Croatia is still not a membership despite its application.

The comparison between the results of the table 2 and the results provided by the table 1 allows us to make several interesting conclusions.

Concerning the impact of the crisis dummy we can make two main remarks. First, this dummy does not have a significant impact on the level of currency substitution if we study the entire sample. Asian crisis affected only Bulgaria, Croatia and Romania. If we specifically study these three economies, we can see that the power of an actual independent central bank to inverse the growth of dollars and euros in the domestic economy is quite poorer. Contrary to the eight other economies we can affirm that Bulgaria, Croatia and Romania are highly dollarized. 
Table 2. Impact of Time-specific and Individual-invariant Characteristics

\begin{tabular}{|c|c|c|c|c|c|c|c|}
\hline & & Fixed Effects & Random Effects & Fixed Effects & Random Effects & Fixed Effects & Random Effects \\
\hline \multirow[t]{6}{*}{$\begin{array}{l}\text { Endogenous } \\
\text { Variable }\end{array}$} & $\begin{array}{c}m_{t O p t}^{\text {glo }}: \text { currency substitu- } \\
\text { tion }\end{array}$ & & & & & & \\
\hline & Constant & & $\begin{array}{l}2.691^{* *} \\
(0.252)\end{array}$ & & $\begin{array}{l}2.532^{* *} \\
(0.585)\end{array}$ & & $\begin{array}{c}2.68^{*} \\
(0.563)\end{array}$ \\
\hline & 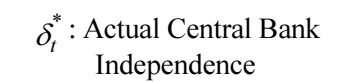 & $\begin{array}{l}-0.67^{* *} \\
(0.14)\end{array}$ & $\begin{array}{l}-0.62^{* *} \\
(0.09)\end{array}$ & $\begin{array}{l}-0.144^{*} \\
(0.068)\end{array}$ & $\begin{array}{l}-0.163^{*} \\
(0.087)\end{array}$ & $\begin{array}{l}-0.684^{* *} \\
(0.176)\end{array}$ & $\begin{array}{l}-0.666^{* *} \\
(0.225)\end{array}$ \\
\hline & $\begin{array}{c}\varphi_{t}^{g l o}: \text { Domestic inflation } \\
\text { instability }\end{array}$ & & & & & $\begin{array}{l}0.027^{*} \\
(0.009)\end{array}$ & $\begin{array}{l}0.103^{*} \\
(0.057)\end{array}$ \\
\hline & $\begin{array}{c}y_{t}^{*_{-}}: \text {Potential Economic } \\
\text { Growth }\end{array}$ & & & & & $\begin{array}{l}-1.07 \\
(0.155)\end{array}$ & $\begin{array}{l}-1.77 \\
(1.131)\end{array}$ \\
\hline & $\begin{array}{c}(U D F M)_{t}: \text { Financial Devel- } \\
\text { opment }\end{array}$ & $\begin{array}{l}-0.451 \\
(0.347)\end{array}$ & $\begin{array}{l}-0.447 \\
(0.543)\end{array}$ & $\begin{array}{c}0.8 \\
(0.679)\end{array}$ & $\begin{array}{l}-0.314 \\
(0.283)\end{array}$ & $\begin{array}{c}0.376 \\
(0.156)\end{array}$ & $\begin{array}{l}-0.147 \\
(0.087)\end{array}$ \\
\hline \multirow{6}{*}{$\begin{array}{l}\text { Exogenous } \\
\text { Variables }\end{array}$} & $(C O R)_{t}$ : Informal Economy & $\begin{array}{l}0.012^{*} \\
(0.006)\end{array}$ & $\begin{array}{l}0.023^{* *} \\
(0.008)\end{array}$ & $\begin{array}{l}0.102 \\
(0.247)\end{array}$ & $\begin{array}{l}0.078^{*} \\
(0.037)\end{array}$ & $\begin{array}{l}-0.003 \\
(0.134)\end{array}$ & $\begin{array}{c}-0.015 \\
(0.0178)\end{array}$ \\
\hline & $\begin{array}{l}\text { ers }: \text { Official Exchange rate } \\
\text { regime }\end{array}$ & $\begin{array}{l}0.067^{*} \\
(0.023)\end{array}$ & $\begin{array}{l}0.082^{* *} \\
(0.017)\end{array}$ & $\begin{array}{l}0.024^{*} \\
(0.09)\end{array}$ & $\begin{array}{l}0.306^{* *} \\
(0.085)\end{array}$ & $\begin{array}{l}0.045^{*} \\
(0.007)\end{array}$ & $\begin{array}{l}0.053^{* *} \\
(0.009)\end{array}$ \\
\hline & $\begin{array}{l}(\text { Crisis })_{t} \text { : External shocks } \\
\text { for the } 11 \text { economies }\end{array}$ & $\begin{array}{c}0.002 \\
(0.008)\end{array}$ & $\begin{array}{c}0.005 \\
(0.003)\end{array}$ & & & & \\
\hline & $\begin{array}{l}(\text { Crisis })_{t} \text { : External shocks } \\
\text { for the } 3 \text { economies }\end{array}$ & & & $\begin{array}{l}0.451^{*} \\
(0.149)\end{array}$ & $\begin{array}{l}0.146^{*} \\
(0.052)\end{array}$ & & \\
\hline & $\begin{array}{l}(\text { in })_{t}: \text { European Integration } \\
\text { for the } 8 \text { economies }\end{array}$ & & & & & $\begin{array}{l}-0.129^{* *} \\
(0.048)\end{array}$ & $\begin{array}{c}-0.191^{*} \\
(0.09)\end{array}$ \\
\hline & R-squared & 0.486 & 0.497 & 0.236 & 0.411 & 0.475 & 0.451 \\
\hline \multicolumn{2}{|c|}{ Adjusted R-squared } & 0.413 & 0.454 & 0.109 & 0.386 & 0.398 & 0.442 \\
\hline \multicolumn{2}{|c|}{ Number of observations } & 143 & 143 & 39 & 39 & 104 & 104 \\
\hline \multicolumn{2}{|c|}{ Trans. Durbin-Watson } & 1.428 & & 1.21 & & 1.489 & \\
\hline \multicolumn{2}{|r|}{ Hausman Test } & \multicolumn{2}{|c|}{0.026} & \multicolumn{2}{|c|}{0.011} & \multicolumn{2}{|c|}{0.045} \\
\hline
\end{tabular}

Notes: Numbers in parenthesis under coefficients are standard errors.

$* *$ and $*$ denotes significance at $1 \%$ and $5 \%$ respectively.

The "Trans. Durbin Watson" value is the one after performing a Cochrane-Orcutt estimation.

The value related to the Hausman Test is the $p$-value.

The 3 economies for "(Crisis $)_{t}$ : External shocks for the 3 economies" are Bulgaria, Croatia and Romania.

The eight economies for " $(\text { in })_{t}$ : European Integration for the 8 economies" are Czech Republic, Estonia, Hungary, Latvia, Lithuania, Poland, Slovakia and Slovenia. 
The influence of the European integration of 2004 is significant and may have represented an important sign of credibility and safety for private agents. This integration may explain an important part of the decreasing level of currency substitution observed in most of these eight economies over last years

\section{Conclusion}

In this paper, we build a model based on a confrontation between authorities implementing monetary policies and private agents asking for foreign currencies. The choice of the appropriate monetary policy depends on a time-inconsistency problem where a partly-independent and conservative central bank is faced with a type of monetary targeting. The authorities have to find a balance between output volatility and money supply growth. The motives of the private agents in asking for foreign currencies are precautionary and/or speculative. The dynamics of the exchange rates partly depend on the level of currency substitution.

The optimal aggregate growth in foreign currencies proves that an independent, conservative central bank and the transparency of its decisions are essential to limit the number of deposits in foreign currencies. At the same time, these optima show that the domestic currency and the foreign currencies are interdependent: the inflation instability of each of the currency can influence the evolution of the holdings of all of them. The complexity of the process of currency substitution is, therefore, better appreciated.

We then propose a new measurement of the actual level of central bank independence, which is based on the progressive implementation of the change of the statutes of the central bank. For the potential output, we use the last measure which has been developed in literature: the HP Filter. We also add institutional determinants such as the size of the informal sector, the under-development of the financial markets and the official exchange rate regime.

We tested for possible endogeneity and concluded that the measure of informal economy with monetary aggregates might be highly correlated with our variable of currency substitution. To capture the effect of informal economy we use the level of corruption on a yearly basis. This new measure has a strong positive effect on the level of currency substitution.

The results of our regressions show that the index of progressive central bank independence is a more powerful determinant than that of classical independence. It is, therefore, advisable to integrate a period of implementation of the laws when 
we want to analyze the impact of the rules which insist on greater legal independence of the monetary authorities. Another interesting result concerns the influence of hard pegs on currency substitution. According to our results harder pegs may create counterproductive effects and may lead to more currency substitution. The implementation of such regimes may reveal to private agents the inability of the authorities to stabilize the economy. The adoption of currency boards by Baltic States and Bulgaria were all made in extreme circumstances with deep monetary crises.

In terms of recommendations, the main instruments for reducing currency substitution are the development of the financial markets, the fight against the informal sector and the building up of credible monetary authorities. In this paper, we have used the concepts of independence and conservativeness to determine this credibility but other concepts could be used and should be analyzed further. Finally, we distinguished the successful sample from the unsuccessful one. We introduced two dummies with time-specific and individual-invariant characteristics. The presence of strong external overall shocks like the Asian crisis of 1997 affected mainly Bulgaria, Croatia and Romania. In these three economies the power of conservative independent central banks has been considerably reduced. Eventually the influence of the European integration of 2004 is significant and may have represented an important sign of credibility and safety for private agents. This integration may explain an important part of the decreasing level of currency substitution observed in most of the "eight economies" over last years.

Received 20 December 2008, Revised 02 September 2009, Accepted 07 September 2009 


\section{Appendices}

ANNEX 1: Rates of Currency Substitution (\% of the deposits in foreign currencies)

\begin{tabular}{|c|c|c|c|c|c|}
\hline & & \multicolumn{2}{|l|}{1996} & \multicolumn{2}{|c|}{2005} \\
\hline \multirow[t]{5}{*}{$\overline{\mathrm{CEE}}$} & Average & & 26.4 & & 27.0 \\
\hline & Median & & 16.2 & & 16.8 \\
\hline & Maximum & Croatia & 67.6 & Croatia & 60.3 \\
\hline & Minimum & Czech Republic & 6.7 & Hungary & 5.1 \\
\hline & Stdard Dev, & & 21.7 & & 15.4 \\
\hline \multirow[t]{5}{*}{ CIS } & Average & & 34.2 & & 48.4 \\
\hline & Median & & 28.8 & & 43.3 \\
\hline & Maximum & Armenia & 58.4 & Georgia & 77.5 \\
\hline & Minimum & Uzbekistan & 10.2 & Uzbekistan & 7.3 \\
\hline & Stdard Dev, & & 15.5 & & 18.1 \\
\hline \multirow[t]{5}{*}{ Latin America } & Average & & 41.1 & & 47.4 \\
\hline & Median & & 37.0 & & 40.2 \\
\hline & Maximum & Bolivia & 89.0 & Bolivia & 88.0 \\
\hline & Minimum & Dominica & 1.1 & Dominica & 3.1 \\
\hline & Stdard Dev, & & 28.4 & & 34.7 \\
\hline \multirow[t]{5}{*}{$\begin{array}{l}\text { Industrial } \\
\text { Countries }\end{array}$} & Average & & 8.1 & & 8.8 \\
\hline & Median & & 6.0 & & 5.5 \\
\hline & Maximum & United Kingdom & 23.2 & $\begin{array}{l}\text { United King- } \\
\text { dom }\end{array}$ & 26.3 \\
\hline & Minimum & Japan & 1.8 & Japan & 1.7 \\
\hline & Stdard Dev, & & 6.8 & & 7.2 \\
\hline
\end{tabular}

CEE: Bulgaria; Croatia; Czech Republic; Estonia; Hungary; Latvia; Lithuania; Poland; Romania; Slovenia; Slovakia

CIS: Armenia; Azerbaijan; Belarus; Georgia; Moldova; Russia; Tajikistan; Ukraine; Uzbekistan

Latin America: Argentina; Bolivia; Costa Rica; Dominica; Ecuador; El Salvador; Honduras; Nicaragua; Paraguay; Peru

Industrial Countries: Australia; Austria; Belgium; Canada; Denmark; France; Germany; Ireland; Italy; Japan; UK; USA 
ANNEX 2: Legal Central Bank Independence

\begin{tabular}{ccc}
\hline & Cukierman Index & GMT Index \\
\hline Australia & 0.31 & 9 \\
Austria & 0.58 & 9 \\
Belgium & 0.19 & 7 \\
Bulgaria & 0.55 & 15 \\
Canada & 0.46 & 11 \\
Croatia & 0.44 & 11 \\
Czech Republic & 0.73 & 13 \\
Denmark & 0.47 & 8 \\
Estonia & 0.78 & 13 \\
France & 0.28 & 7 \\
Germany & 0.66 & 13 \\
Hungary & 0.67 & 10 \\
Ireland & 0.39 & 7 \\
Italy & 0.22 & 5 \\
Japan & 0.16 & 6 \\
Latvia & 0.49 & 12 \\
Lithuania & 0.78 & 15 \\
Poland & 0.89 & 15 \\
Romania & 0.34 & 12 \\
Slovak Republic & 0.62 & 11 \\
Slovenia & 0.63 & 11 \\
UK & 0.31 & 6 \\
USA & 0.51 & 12 \\
\hline Average of Industrial Economies & 0.38 & 8.33 \\
Average of Transition Economies & 0.63 & 12.55 \\
\hline
\end{tabular}


ANNEX 3: Composition of the GMT Index

\begin{tabular}{|c|c|c|c|c|c|c|c|c|c|c|c|c|c|c|c|c|c|c|c|c|}
\hline & G1 & G2 & G3 & B4 & B5 & R6 & R7 & $\mathrm{C} 8$ & C9 & PI & D10 & D11 & D12 & D13 & D14 & D15 & M16 & M17 & EI & OI \\
\hline Estonia 93 & * & & * & ${ }^{*}$ & & & $*$ & $*$ & * & 6 & * & * & * & * & * & * & * & & 7 & 13 \\
\hline Latvia 92 & * & * & * & $*$ & $*$ & $*$ & * & $*$ & $*$ & 9 & * & & & * & & & * & & 3 & 12 \\
\hline Lithuania 91 & * & & & $*$ & $*$ & $*$ & & $*$ & & 5 & & & & * & & & * & & 2 & 7 \\
\hline Lithuania 96 & * & & * & $*$ & $*$ & $*$ & * & $*$ & * & 8 & * & * & * & * & * & * & * & & 7 & 15 \\
\hline Lithuania 04 & * & & * & & $*$ & $*$ & & $*$ & * & 6 & * & * & * & * & * & * & * & & 7 & 13 \\
\hline Hungary 91 & & * & * & & & & & $*$ & & 3 & * & $*$ & $*$ & * & & & * & * & 6 & 9 \\
\hline Hungary 97 & & * & * & & & & & $*$ & & 3 & $*$ & $*$ & $*$ & $*$ & $*$ & & $*$ & $*$ & 7 & 10 \\
\hline Hungary 99 & * & * & * & & $*$ & $*$ & * & $*$ & & 7 & * & * & * & * & * & * & * & * & 8 & 15 \\
\hline Czech Rep 92 & * & * & * & $*$ & $*$ & & * & $*$ & * & 8 & * & & * & * & & * & * & & 5 & 13 \\
\hline Slovakia 92 & & * & * & & & & * & $*$ & * & 5 & $*$ & & $*$ & $*$ & & $*$ & $*$ & $*$ & 6 & 11 \\
\hline Slovenia 91 & $*$ & * & & $*$ & $*$ & $*$ & * & $*$ & & 7 & * & & * & * & & & * & & 4 & 11 \\
\hline Poland 89 & * & & & $*$ & & $*$ & & $*$ & & 4 & * & & & * & & * & * & & 4 & 8 \\
\hline Poland 92 & * & * & * & $*$ & & $*$ & & $*$ & & 6 & * & & & * & & * & * & & 4 & 10 \\
\hline Poland 97 & * & * & * & $*$ & $*$ & & * & $*$ & & 7 & * & $*$ & $*$ & * & * & * & * & & 7 & 14 \\
\hline Poland 99 & * & * & * & $*$ & $*$ & $*$ & * & $*$ & & 8 & * & * & $*$ & * & * & * & * & & 7 & 15 \\
\hline Croatia 92 & $*$ & * & & $*$ & & $*$ & * & $*$ & $*$ & 7 & * & & * & * & & & * & & 4 & 11 \\
\hline Romania 91 & & * & & & $*$ & $*$ & & $*$ & & 4 & * & & & $*$ & & & * & & 3 & 7 \\
\hline Romania 98 & & * & & & $*$ & $*$ & * & $*$ & & 5 & $*$ & & & * & * & * & * & & 5 & 10 \\
\hline Romania 04 & & * & & & $*$ & $*$ & * & $*$ & & 5 & * & * & * & * & * & $*$ & * & & 7 & 12 \\
\hline Bulgaria 91 & * & & * & $*$ & & $*$ & * & $*$ & * & 7 & $*$ & & $*$ & $*$ & $*$ & & $*$ & & 5 & 12 \\
\hline Bulgaria 96 & * & & & $*$ & & $*$ & * & $*$ & * & 6 & * & & * & * & * & & * & & 5 & 11 \\
\hline Bulgaria 97 & $*$ & * & & $*$ & $*$ & $*$ & $*$ & $*$ & $*$ & 8 & $*$ & $*$ & $*$ & $*$ & $*$ & $*$ & $*$ & & 7 & 15 \\
\hline \multicolumn{9}{|c|}{ Sources: national legislation (BNR, NBP,...) } & \multicolumn{12}{|c|}{ C: Constitution } \\
\hline \multicolumn{9}{|c|}{ PI: Political independence } & \multicolumn{12}{|c|}{ C8: Statutory responsibility to pursue monetary stability } \\
\hline \multicolumn{9}{|c|}{ EI: Economic independence } & \multicolumn{12}{|c|}{ C9: D: Direct credit to the government } \\
\hline \multicolumn{9}{|c|}{ OI: Overall independence $(\mathrm{PI}+\mathrm{EI})$} & \multicolumn{12}{|c|}{ D10: Direct credit facility is not automatic } \\
\hline \multicolumn{9}{|l|}{ G: Government } & \multicolumn{12}{|c|}{ D11: Direct credit facility is at the market interest rate } \\
\hline \multicolumn{9}{|c|}{ G1: Governor not appointed by the government } & \multicolumn{12}{|c|}{ D12: Direct credit facility is temporary } \\
\hline \multicolumn{9}{|c|}{ G2: Governor appointed for more than five years } & \multicolumn{12}{|c|}{ D13: Direct credit facility is of limited amount } \\
\hline \multicolumn{9}{|c|}{ G3: Provisions for governor's dismissal non political only } & \multicolumn{12}{|c|}{ D14: $C B$ does not participate in the primary market } \\
\hline \multicolumn{9}{|c|}{ B: Governing BoardB4: None of the board appointed by the government } & \multicolumn{12}{|c|}{ D15: All direct credit is securitized } \\
\hline \multicolumn{9}{|c|}{ B5: Board appointed for more than 5 years } & \multicolumn{12}{|c|}{ M: Monetary instruments } \\
\hline \multicolumn{9}{|c|}{ R: Relation with the government } & M16: & scou & rate is & et by th & central & bank & & & & & & \\
\hline R6: No mandatory & overnı & ent re & sentat & in & oar & & & & M17: & uper & ision 0 & comm & cial ba & nks is & ot er & ruste & th & cent & & **) or \\
\hline
\end{tabular}


ANNEX 4: Complete Data

\begin{tabular}{cccc}
\hline & \multicolumn{3}{l}{ Details of the 163 Observations } \\
\hline Economies & Range & Economies & Range \\
Bulgaria & $1993-2007$ & Lithuania & $1994-2007$ \\
Croatia & $1993-2007$ & Poland & $1992-2007$ \\
Czech Republic & $1993-2007$ & Romania & $1993-2007$ \\
Estonia & $1994-2007$ & Slovakia & $1994-2007$ \\
Hungary & $1993-2007$ & Slovenia & $1993-2007$ \\
Latvia & $1993-2007$ & & \\
\hline
\end{tabular}

ANNEX 5: Estimation of with Ordinary Least Squares Method

\begin{tabular}{|c|c|c|c|c|c|c|c|}
\hline Economies & $\beta$ & Economies & $\beta$ & Economies & $\beta$ & Economies & $\beta$ \\
\hline Bulgaria & $\begin{array}{c}0.51 \\
(0.06)\end{array}$ & Estonia & $\begin{array}{c}0.79 \\
(0.02)\end{array}$ & Lithuania & $\begin{array}{c}0.55 \\
(0.03)\end{array}$ & Slovakia & $\begin{array}{c}0.33 \\
(0.08)\end{array}$ \\
\hline Croatia & $\begin{array}{c}0.5 \\
(0.07)\end{array}$ & Hungary & $\begin{array}{c}0.29 \\
(0.05)\end{array}$ & Poland & $\begin{array}{c}0.39 \\
(0.09)\end{array}$ & Slovenia & $\begin{array}{c}0.44 \\
(0.04)\end{array}$ \\
\hline Czech Republic & $\begin{array}{c}0.42 \\
(0.08)\end{array}$ & Latvia & $\begin{array}{c}0.49 \\
(0.07)\end{array}$ & Romania & $\begin{array}{c}0.77 \\
(0.04)\end{array}$ & & \\
\hline
\end{tabular}

ANNEX 6: Official Exchange Rate Regimes

\begin{tabular}{|c|c|c|c|c|c|c|c|c|c|c|c|}
\hline Year & Bulgaria & Croatia & Czech R. & $\begin{array}{c}\text { Esto- } \\
\text { nia }\end{array}$ & $\begin{array}{l}\text { Hun- } \\
\text { gary }\end{array}$ & Latvia & $\begin{array}{c}\text { Lithua } \\
\text { nia }\end{array}$ & $\begin{array}{c}\text { Polan } \\
\mathrm{d}\end{array}$ & $\begin{array}{l}\text { Roma- } \\
\text { nia }\end{array}$ & Slovakia & Slovenia \\
\hline 1990 & 6 & & 6 & & 6 & & & 6 & 6 & 6 & \\
\hline 1991 & 1 & & 6 & 1 & 6 & & & 6 & 3 & 6 & \\
\hline 1992 & 1 & 6 & 6 & 7 & 6 & 2 & 1 & 5 & 3 & 6 & 5 \\
\hline 1993 & 1 & 2 & 6 & 7 & 6 & 2 & 1 & 5 & 3 & 6 & 5 \\
\hline 1994 & 1 & 2 & 6 & 7 & 6 & 7 & 7 & 5 & 3 & 6 & 5 \\
\hline 1995 & 1 & 2 & 6 & 7 & 5 & 7 & 7 & 3 & 3 & 6 & 5 \\
\hline 1996 & 1 & 2 & 2 & 7 & 5 & 7 & 7 & 3 & 3 & 2 & 5 \\
\hline 1997 & 7 & 2 & 2 & 7 & 5 & 7 & 7 & 3 & 3 & 2 & 5 \\
\hline 1998 & 7 & 2 & 1 & 7 & 5 & 7 & 7 & 3 & 3 & 2 & 5 \\
\hline 1999 & 7 & 2 & 1 & 7 & 5 & 7 & 7 & 3 & 3 & 1 & 5 \\
\hline 2000 & 7 & 2 & 1 & 7 & 5 & 7 & 7 & 3 & 3 & 1 & 5 \\
\hline 2001 & 7 & 2 & 1 & 7 & 3 & 7 & 7 & 0 & 3 & 1 & 5 \\
\hline 2002 & 7 & 2 & 1 & 7 & 2 & 7 & 7 & 0 & 3 & 1 & 5 \\
\hline 2003 & 7 & 2 & 1 & 7 & 2 & 7 & 7 & 0 & 3 & 1 & 5 \\
\hline 2004 & 7 & 2 & 1 & 7 & 2 & 7 & 7 & 0 & 3 & 1 & 2 \\
\hline 2005 & 7 & 2 & 1 & 7 & 2 & 7 & 7 & 0 & 3 & 1 & 2 \\
\hline 2006 & 7 & 2 & 1 & 7 & 2 & 7 & 7 & 0 & 3 & 1 & 2 \\
\hline 2007 & 7 & 2 & 1 & 7 & 2 & 7 & 7 & 0 & 3 & 1 & 2 \\
\hline \multicolumn{12}{|c|}{$\begin{array}{l}\text { Notes: } \\
\text { 7: formal or de facto currency board } \\
\text { 6: peg to a currency or to a basket with fluctuation margins less than or equal to }+2.25 \% \\
\text { 5: float with active management by monetary authorities (implicit crawling peg) } \\
\text { 4: float with active management monetary authorities (implicit crawling band) } \\
\text { 3: crawling peg with fluctuation margins of more than }+2.25 \% \\
\text { 2: peg to a currency or a basket with fluctuation margins of more than } 2.25 \% \\
\text { 1: float with intervention } \\
\text { 0: free float without any intervention. In parentheses are the de jure regimes for Croatia, Romania and Slovenia. Shaded areas } \\
\text { denote a regime shift }\end{array}$} \\
\hline
\end{tabular}




\section{References}

Agenor, P. R.(2001), "Monetary Policy Under Flexible Exchange Rates: an Introduction to Inflation Targeting", Central Bank of Chile Working Paper No. 124.

Alesina, A. and R. J. Barro(2002), "Currency Unions", Quarterly Journal of Economics, 117(2), pp. 409-436.

Alpanda, S., A. Honig(2008), "Political Monetary Cycles and a New de facto Ranking of Central Bank Independence", Working Paper Series, Amherst College, Amherst, MA 01002.

Arnone, M., B. J. Laurens, J. F. Segalotto(2006), "Measures of Central Bank Autonomy: Empirical Evidence for OECD, Developing, and Emerging Market Economies", IMF Working Paper, WP/06/228.

Richard C. B. and S. Ho Mun(1996), "Sunspots, Currency Substitution, and Inflationary Finance", Journal of International Economics, 41(1-2), pp. 73-93.

Benes, J. and P. N'Diaye(2004), "A Multivariate Filter for Measuring Potential Output and the NAIRU: Application to the Czech Republic", IMF Working Paper WP/04/ 45.

Benigno, P.(2004), "Optimal Monetary Policy in a Currency Area”, Journal of International Economics, 63(2), pp. 293-320.

Bleakley, H. and K. Cowan(2008), "Corporate Dollar Debt and Depreciations: Much Ado about Nohing?", Review of Economics and Statistics, 90(4), pp. 612-626.

Brada, J. C., A. M. Kutan(2003), "The End of Moderate Inflation in Three Transition Economies?", Working Paper Series, Federal Reserve Bank of St. Louis, Research Division, 411 Locus Street St. Louis, MO 63102.

Calvo, G. A., and C. Reinhart(2002), "Fear of Floating”, Quarterly Journal of Economics, 117(2), pp. 379-408.

Chang, R., and A. Velasco(2006), "Currency Mismatches and Monetary Policy: a Tale of Two Equilibria”, Journal of International Economics, 69(1), pp. 150-175.

Cowan, K. and Q. T. Do(2003), "Financial Dollarization and Central Bank Credibility", The World Bank, Policy Research Working Paper series; no. WPS 3082.

Cukierman, A.(1992), Central Bank Strategy, Credibility and Independence: Theory and Evidence, The MIT Press, Cambridge, MA.

Cukierman, A., Webb, S. and Neyapti, B.(1992), "Measuring the Independence of Central Bank and its Effects on Policy Outcomes", World Bank Economic Review, 6, pp. 353598.

Cukierman, A., G. P. Miller and B. Neyapti(2000), "Central Bank Reform, Liberalization and Inflation in Transition Economies-an International Perspective", Centre for Economic Research, No. 2000-106.

De Melo, M., D. Cevdet, and A. Gelb(1996), "Patterns of Transition from Plan to Market", World Bank Economic Review, 10(3), pp. 397-424.

Devereux, M. B., and A. Sutherland(2007), "Monetary Policy and Portfolio Choice in an 
Open Economy Macro Model", Journal of the European Economic Association, 5(23), pp. 491-499.

Eijffinger, S. C. W., and E. Schaling(1993), "Central Bank Autonomy in Twelve Industrial Economies”, Banca Nazionale del Lavoro Quarterly Review, Vol. 184, pp. 49-89.

Eijffinger S. and van Keulen, M.(1995), "Central Bank Independence in Another Eleven Economies", Banca Nazionale del Lavoro Quarterly Review, 192, pp. 39-83.

Eijffinger, S. C. W. and J. D. Haan(1996), "The Political of Central Bank Independence", Special Papers in International Economics, No. 19.

Eijffinger, S. C. W. and M. Hoeberichts (1998), "The Trade Off between Central Bank Independence and Conservativeness", Oxford Eco. Papers, Oxford University Press, 50(3), pp. 397-411.

Feige E., M. Faulend, V. Sonje and V. Sosic V.(2001), "Unofficial Dollarization in Latin America:

Currency Substitution, Network Externalities and Irreversibility", Westview Pr.

Feige, Edgar, L. and J. Dean(2002), "Dollarization and Euroization in Transition Countries : Currency Substitution", Oxford University Press. 2002c.

Fisher, I.(1911), The Purchasing Power of Money: Its Determination and Relation to Credit, Interest, and Crises, New York: The Macmillan Co.

Freitas, de L.(2004), "The Dynamics of Inflation and Currency Substitution in a Small Open Economy", Journal of International Money and Finance 23, pp.133-142.

Friedman, M.(1971), "Government Revenue from Inflation", Journal of Political Economy, 79(4), pp. 846-856.

Giorno, C., P. Richardson, D. Roseveare and P. Van den Noord(1995), "Estimating Potential Output, Output Gaps and Structural Budget Balances", OECD Economics Department, Working Paper, 152.

Gale, D. and X. Vives(2002), "Dollarization, Bailouts, and the Stability of the Banking System", Quarterly Journal of Economics, 117(2), pp. 467-502.

Grilli, V., D. Masciandaro, and G. Tabellini(1991), "Political and Monetary Institutions and Public Financial Policies in the Industrial Economies", Economic Policy, Vol.13, pp. 341-92.

Hausman, J. A.(1979), "Specification Tests in Econometrics", Econometrica, 46, pp.1251-71.

Honohan, P., G. De Nicolo and A. Ize(2003), "Dollarization of the Banking System: Good or Bad?", The World Bank, Policy Research Working Paper No. 3116.

$\mathrm{Hu}$, Y.(2003), "Empirical Investigations of Inflation Targeting”, PhD (chap 3), Department of Economics, Georgetown University, Institute for International Economics.

Ize A., and E. Yeyati Levy(2005), “Financial Dollarization: Is It for Real?", IMF Working Paper, Monetary and Financial System Department.

Ize, A. and E. Levy-Yeyati(2003), "Financial Dollarization", Journal of International Economics, 59(2), pp. 323-347.

Jacome, L. and F. Vazquez(2005), “Any Link between Legal Central Bank Independence 
and Inflation? Evidence from Latin America and the Caribbean", IMF Working Paper, 05/75.

Jalil A., and Y. Ma(2008), "Financial Development and Economic Growth: Time Series Evidence from Pakistan and China", Journal of Economic Cooperation, 29(2), pp. 29-68.

Levy-Yeyati, E.(2006), "Financial Dollarization: Evaluating the consequences", Economic Policy, 21(45), pp. 61-118.

Lougani, P., and Sheets, N.(1997), "Central Bank Independence, Inflation, and Growth in Transition Economies", Journal of Money Credit and Banking, 29, pp. 381-399.

Lustig, H., and A. Verdelhan(2006), "Investing in Foreign Currency is like Betting on your Intertemporal Marginal Rate of Substitution", Journal of the European Economic Association, 4(2-3), pp. 644-655.

Maliszewski, W. S.(2000), "Central Bank Independence in Transition Economies", Economics of Transition, 8(3), pp. 749-789.

Mangano, G.(1998), "Measuring Central Bank: a Tale of Subjectivity and of its Consequences", Oxford Economic Papers, 50, 468-492.

Piontkovsky, R.(2003), "Dollarization, Inflation Volatility and Underdeveloped Financial Markets in Transition Economies", Eco Education and Research Consortium, W-P $03 / 02$.

Rennhack, R. and M. Nozaki(2006), "Financial Dollarization in Latin America", IMF Working Paper No. 06/7.

Rogoff, K.(1985), “The Optimal Degree of Commitment to an Intermediate Monetary Target”, Quarterly Journal of Economics, 100, 1169-90.

Schneider, F. and B. Frey(2000), "Informal and Underground Economy", Economics Working Papers 2000-04, Department of Economics, Johannes Kepler University Linz, Austria.

Shambaugh, Jay C.(2004), "The Effect of Fixed Exchange Rates on Monetary Policy", Quaterly Journal of Economics, 119(1), pp. 301-352.

Shang-Jin, W.(2000), "How Taxing is Corruption on International Investors?", Review of Economics and Statistics, 82(1), pp. 1-11.

Thomas, L. R.(1985), "Portfolio in a Dollarized Economy", Journal of Money, Credit and Banking, Blackwell Publishing, 17(3), pp. 347-57.

Vetlov, I.(2001), "Dollarization in Lithuania: an Econometric Approach", Bank of Lithuania, BOFIT Discussion Paper No. 1/2001. 